ISSN 2414-1143

Научный альманах стран Причерноморья. 2019. Том 19. № 3

DOI 10.23947/2414-1143-2019-19-3-52-60

UDC 504.455(28)

\title{
HYDROCHEMICAL SITUATION IN THE TSIMLYANSK RESERVOIR ACCORDING TO THE RESULTS OF OBSERVATIONS IN 2011-2018
}

\author{
๑ Alexey V. Kleschenkov, Tatyana B. Filatova, Viktoriya S. Gerasyuk \\ Federal State Budgetary Institution of Science "Federal Research Center the Southern \\ Scientific Center of the Russian Academy of Sciences", \\ Rostov-on-Don, Russian Federation \\ fila5784@mail.ru
}

Tsimlyansk Reservoir is the largest reservoir of the Rostov region and southern Russia. The main factors for the formation of the hydrochemical regime of the Tsimlyansk Reservoir are the chemical composition of the water entering the river runoff and its mixing with the water accumulated in the reservoir. The chemical composition of the surface waters of the Don River basin is characterized by great diversity, which is associated with anthropogenic factors and the difference in the physiographic conditions in which the formation of surface waters takes place. The main sources of pollution of the Don River surface waters are wastewater enterprises of housing and communal services, chemical, petrochemical, metallurgical, agricultural and other industries, shipping and small fleet. The catchment area of the Don is located in the zone of insufficient moisture, which explains the cause of low-flow. The environmental situation in the Don basin, and especially on the Lower Don, is characterized as stressful, and when low-flow years and periods occur in the basin, there may be water shortages that manifest themselves not only in the lack of water of the required quality to meet the needs of the population and economy, but also in the impossibility preservation of necessary conditions for the existence of aquatic and riparian ecosystems. In this regard, the complex study of the hydrological and hydrochemical and hydrobiological conditions in the Tsimlyansk reservoir is becoming increasingly important. The purpose of the research was to study the current hydrochemical state of the Tsimlyansk reservoir, assess the dynamics of changes in the hydrochemical situation in the water column over the period from November 2011 to September 2018, and indirectly estimate the productivity of the Tsimlyansky reservoir water by chlorophyll "a". The published data were analyzed and compared with the results of our own research. The values of the N: P ratio during the observation period, in most cases, indicated the limitation of the primary production by nitrogen. The long-term dynamics of the content of the determined parameters under different water conditions did not have pronounced tendencies; in general, the concentrations of nutrients in all field research are comparable, subject to seasonal fluctuations, are in accordance with natural mechanisms and under anthropogenic influence.

Key words: Tsimlyansk Reservoir, hydrochemical regime, nutrients, productivity, chlorophyll "a".

[А.В. Клещенков, Т.Б. Филатова, В.С. Герасюк Гидрохимическая обстановка в цимлянском водохранилище по результатам наблюдений 2011-2018 гг.]

Цимлянское водохранилище является крупнейшим водохранилищем Ростовской области и юга

России. Основными факторами формирования гидрохимического режима Цимлянского водохранилища является химический состав воды, поступающей с речным стоком, и процессы смешения её с водами, аккумулированными в водохранилище. Химический состав поверхностных вод бассейна р. Дон отличается большим разнообразием, что связано с антропогенными фракторами и различием фризикогеографических условий, в которых происходит фрормирование поверхностных вод. Основными источниками загрязнения поверхностных вод бассейна р. Дон являются сточные воды предприятий жилищно-коммунального хозяйства, химической, нефтехимической, металлургической, сельскохозяйственной и других отраслей промышленности, судоходство и маломерный фрлот. Водосборная площадь Дона расположена в зоне недостаточного увлажнения, что обусловливает причину маловодий. Экологическая обстановка в бассейне Дона, и особенно на Нижнем Дону, характеризуется как напряжённая, а при наступлении маловодных лет и периодов в бассейне возможно возникновение дефицитов водных ресурсов, проявляющихся не только в недостатке воды необходимого качества для удовлетворения потребностей населения и экономики, но и в невозможности сохранения необходимых условий для существования водных и околоводных экосистем. В связи с этим всё большее значение приобретает комплексное изучение гидролого-гидрохимической и гидробиологической обстановки в Цимлянском водохранилище. Целью проведённых исследований являлись изучение современного гидрохимического состояния Цимлянского водохранилища, оценка динамики изменения 
гидрохимической обстановки в водной толще за период времени с ноября 2011 г. по сентябрь 2018 г. и косвенная оценка продуктивности вод Цимлянского водохранилища по содержанию хлорофилла "а". Проанализированы опубликованные данные и сопоставлены с результатами собственных исследований. Величины отношения N:P в период наблюдений, в большинстве случаев, указывали на лимитирование первичной продукции азотом. Многолетняя динамика содержания определяемых параметров в условиях различной водности не имела выраженных тенденций, в целом, концентрации биогенных веществ во всех экспедиционных исследованиях сопоставимы, подвержены сезонным колебаниям, находятся в соответствии с природными механизмами и под антропогенным влиянием.

Ключевые слова: Цимлянское водохранилище, гидрохимический режим, биогенные вещества, продуктивность, хлорофилл "а".

Alexey V. Kleschenkov - Leading Research Fellow, Ph.D. in Geography, Federal Research Center the Southern Scientific Center of the Russian Academy of Sciences, Rostov-on-Don, Russian Federation.

Tatyana B. Filatova - Research Fellow, Federal Research Center the Southern Scientific Center of the Russian Academy of Sciences, Rostov-on-Don, Russian Federation.

Viktoriya S. Gerasyuk - Junior Research Fellow, Federal Research Center the Southern Scientific Center of the Russian Academy of Sciences, Rostov-on-Don, Russian Federation.

Клещенков Алексей Владимирович - ведущий научный сотрудник, кандидат географических наук, Федеральный исследовательский чентр Южный научный центр Российской академии наук (ЮНЦ РАН), г. Ростов-на-Дону, Российская Федерация.

Филатова Татьяна Борисовна - научный сотрудник, Федеральный исследовательский центр Южный научный центр Российской академии наук (ЮНЦ РАН), г. Ростов-на-Дону, Российская Федерация.

Герасюк Виктория Сергеевна - младший научный сотрудник, Федеральный исследовательский центр Южный научный центр Российской академии наук (ЮНЦ РАН), г. Ростов-на-Дону, Российская Федерация.

This research work was carried out on materials collected by the staff of the Southern Scientific Center of the Russian Academy of Sciences during the expeditions of 2011-2018, of which 2011 and 2015 belong to the category of low-flow years, and in 2018 to the category of high-flow. Hydrochemical observations included determination of the active reaction medium $(\mathrm{pH})$, dissolved oxygen concentration (DOC), nitrite content, nitrate, ammonium ions, dissolved nitrogen, gross nitrogen, phosphates, dissolved phosphorus, total phosphorus, silica, chlorophyll «a» of total suspended solids.

For hydrochemical studies, water samples were taken in accordance with the requirements of the Manuals ... [2] with the Molchanov bathometer from the surface and shallow horizons. Concentrations of dissolved nutrients were determined in the stationary laboratory of the Southern Scientific Center: phosphates were checked by the method of Morphy and Riley; nitrites according to the method of Bendschneider and Robinson; nitrates according to the method of Morris and Riley (modified by Grasshoff; Strickland and Parsons; Sapozhnikov, Gusarovoy, Lukashev); concentrations of bulk nitrogen and bulk phosphorus by the method of Valderram [6].

During the expedition to the Tsimlyansk reservoir in November 2011, a hydrochemical survey was carried out at 10 stations (see Figure 1). 


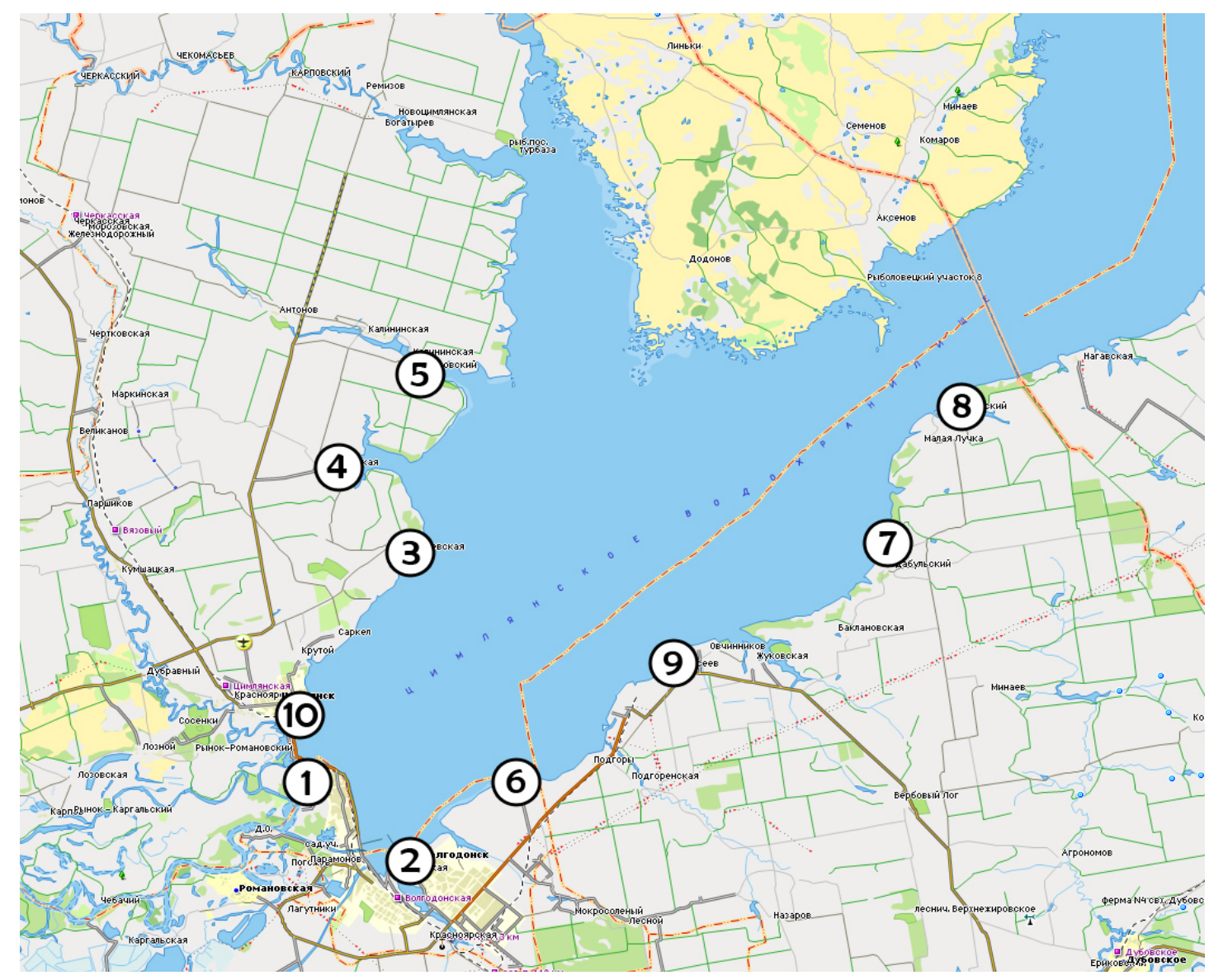

Figure 1. Map of the location of observation stations on the Tsimlyansk reservoir in November 2011.

The data obtained show that the maximum concentrations of ammonium ions $(2.50 \mathrm{mg}$ $\mathrm{N} / \mathrm{l})$, nitrates $(0.55 \mathrm{mg} \mathrm{N} / \mathrm{l})$ and phosphates $(0.14 \mathrm{mg} \mathrm{P} / \mathrm{l})$ were recorded at the southwestern coast of the Tsimlyansk reservoir in the area of art. Ternovskaya (Art. 4). The minimum values of ammonium ( $0.11 \mathrm{mg} \mathrm{N} / \mathrm{l})$ were observed at st. Khoroshevskaya (art. 3). At the same time, the maximum contents of nitrites $(0.05 \mathrm{mg} \mathrm{N} / \mathrm{I})$ and silicon $(8.57 \mathrm{mg} \mathrm{Si} / \mathrm{I})$ were determined at the southeastern shore of the reservoir at stations 9 (Kharseev village) and 8 (Krivsky village). The minimum amount of phosphates and silicon was observed in the coastal waters of Volgodonsk and was $0.025 \mathrm{mgP} / \mathrm{l}$ and $5.752 \mathrm{mgSi} / \mathrm{l}$, respectively. Such a distribution of the maximum concentrations of ammonium ions, nitrates and phosphates can be explained by weather conditions at the time of the expedition work, since it is known [8] that under the action of the east and south winds, the greatest amount of pollution is retained in the Ternovsky arroyo. The maximum nitrite content at stations 8 and 9 is possibly due to fresh pollution.

During the September research in 2015, water samples were taken at 17 stations (see Figure 2). 


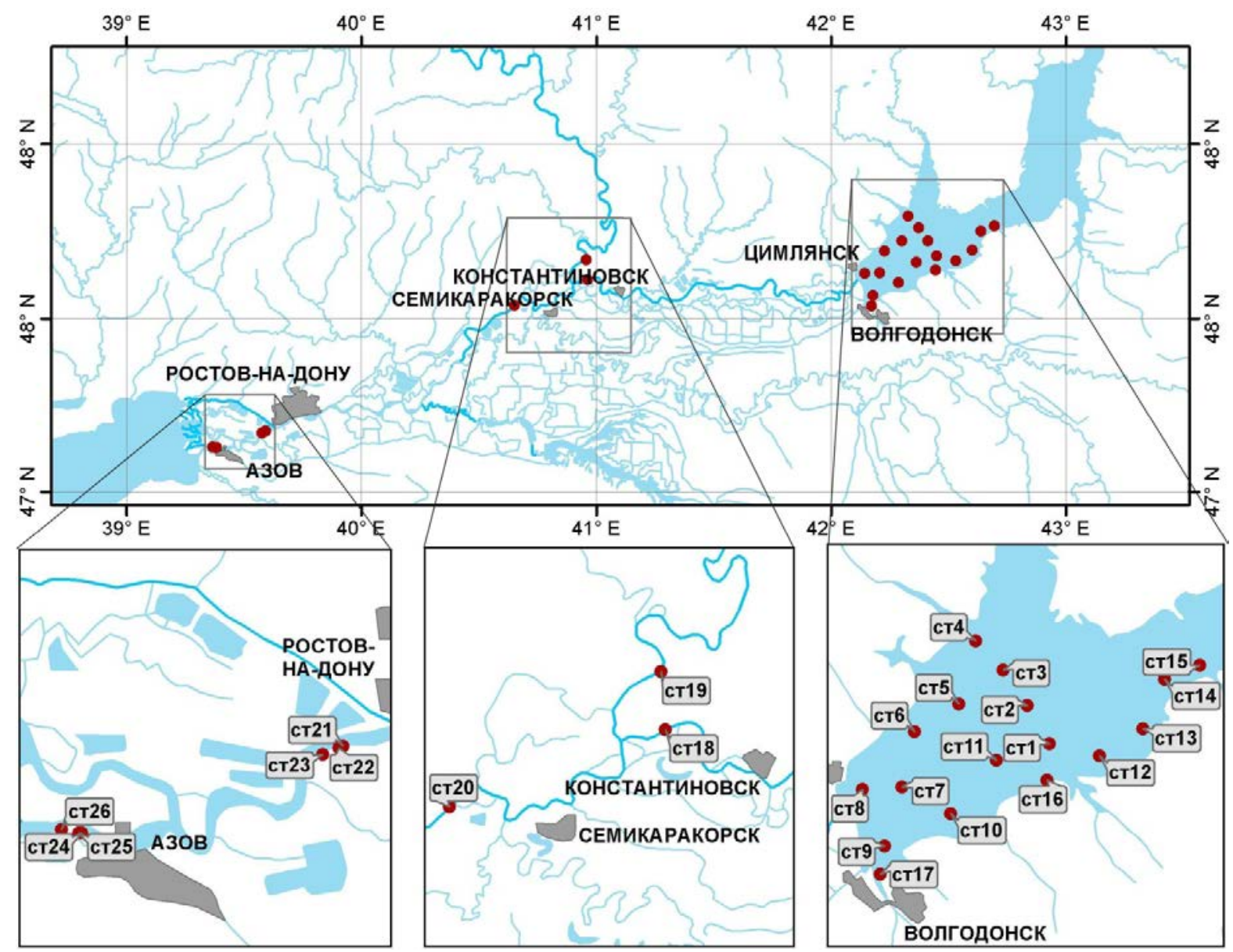

Figure 2. Map of the location of observation stations on the Tsimlyansk reservoir in September 2015.

During the expedition to the Tsimlyansk reservoir in May 2018, a hydrochemical survey was conducted at 21 stations according to '2015 map.

In September 2018, the expedition work in the Tsimlyanskoe reservoir was also performed at 21 stations according to the previous scheme.

When analyzing the results obtained from the data of four expeditions to the Tsimlyanskoe reservoir, comparing them with the values at the stations and averages for the periods of surveys with the values of the hydrochemical parameters to be determined and comparing the data from different years, the following was shown.

The average concentrations of nitrites, nitrates, and silicon recorded during the autumn survey in the low-flow 2011 year were similar, and the average values of the phosphate concentrations differed slightly compared with the corresponding values of the lowflow 2015. The mean concentrations of nitrites, nitrates, and phosphates, recorded during the autumn survey in high-flow 2018, were slightly lower (2.6, 5, and 2 times, respectively).

Seasonal fluctuations in the concentration of ammonium ions are usually characterized by an increase in early autumn with the intensification of the processes of bacterial decay of organic matter during periods of aquatic organisms' death, especially in the areas of their accumulation. In September 2015, the average value of the concentration of ammonium ions $(0.063 \mathrm{mg} / \mathrm{l})$ characterized the reservoir at the time of observations as lowpollution, in September 2018, the concentrations were much higher, and the average concentration of ammonium ions was $0.160 \mathrm{mg} / \mathrm{l}$, characterizing the reservoir as moderately polluted during the shooting period. 
During the observation period, the concentrations of ammonium ions in the waters of the Tsimlyansk reservoir were recorded in the range from $<0.001 \mathrm{mg} / \mathrm{l}$ to $1.06 \mathrm{mg} / \mathrm{l}$ and 2.5 $\mathrm{mg} / \mathrm{l}$, and high concentrations were also recorded in May 2018. Since industrial effluents enterprises contain up to $1 \mathrm{mg} / \mathrm{l}$ of ammonium ions, in household effluent - 2-7 mg/l of ammonium ions [4], then the observed content can be explained by pollution of the reservoir water with wastewater, when the negative anthropogenic impact on the studied area created conditions for ammonium ions.

Nitrates are the final product of the mineralization of organic nitrogen-containing substances, their content in water, as a rule, significantly exceeds the content of ammonium and nitrite nitrogen [5]. This pattern was observed by us only in September 2015, in other cases the content of ammonium ions exceeded, sometimes significantly, (in May 2018) the content of nitrates.

The main process leading to a decrease in the concentration of nitrates is their consumption by phytoplankton and denitrifying bacteria. The concentration of nitrates in surface waters is subject to noticeable seasonal fluctuations: the minimum during the growing season, it increases in autumn and reaches a maximum in winter when nitrogen consumption is minimal, but organic substances decompose and nitrogen passes from organic to mineral forms [9]. The above is confirmed by the data we obtained, when in May 2018 the average nitrate content was only $0.002 \mathrm{mg} / \mathrm{l}$, while in autumn 2011, 2015 and 2018 it was, respectively, $0.376 \mathrm{mgN} / \mathrm{l}, 0,377 \mathrm{mgN} / \mathrm{l}$ and $0.075 \mathrm{mgN} / \mathrm{l}$.

The highest content of nitrites is usually observed by the end of summer, which is associated with the processes of aquatic organisms death and the decomposition of organic residues, as well as an increase in the intensity of the process of nitrate reduction by denitrifying bacteria [3]. These data are confirmed by our results when the average nitrite content was $0.003 \mathrm{mgN} / \mathrm{l}$ in May 2018, and in the fall of 2011, 2015 and 2018 it was, respectively, $0.031 \mathrm{mgN} / \mathrm{l}, 0,026 \mathrm{mgN} / \mathrm{l}$ and $0.010 \mathrm{mgN} / \mathrm{l}$.

In May 2018, during the period of sampling due to the storm, the water column was subjected to wind mixing; the concentration of total suspended solids was distributed over the studied water area, varying slightly, from $1.0 \mathrm{mg} / \mathrm{l}$ to $19.0 \mathrm{mg} / \mathrm{l}$. In September, the expedition was calm, or a weak southerly or south-westerly wind, the sea was 0.25 or $<0.25 \mathrm{~m}$, the total suspension content in the Tsimlyansk reservoir was $2 \mathrm{mg} / \mathrm{l}-136 \mathrm{mg} / \mathrm{l}$. In article [7], suspended matter concentrations up to 50-70 $\mathrm{mg} / \mathrm{l}$ are indicated as maximum for the Don delta and characteristic for spring and summer seasons, which is consistent with our data.

In September 2015, the waters of the Tsimlyansk reservoir were characterized as neutral (average pH value 7.45), and in May and September 2018 as slightly alkaline (average $\mathrm{pH}$ values 8.35 and 8.38). The $\mathrm{pH}$ value of water is one of the most important indicators of water quality. The concentration of hydrogen ions is of great importance for chemical and biological processes occurring in natural waters, the development and vital activity of aquatic plants, the stability of various forms of biogenic elements and the transformation processes and the ratio of these forms, the toxicity of pollutants depend on $\mathrm{pH}$.

Dissolved forms of silicon in waters are represented mainly by silicic acid, the products of its dissociation and association, and organosilicon compounds. In a slightly alkaline medium, the degree of polymerization is maximal; therefore, the proportion of polymeric forms of silicic acids increases, which means that during the expedition work in the spring and autumn of 2018, silicon was represented by polysilicic acids.

Also, phosphates in water may be present in the form of various ions, depending on the $\mathrm{pH}$ value. In the $\mathrm{pH}$ range of $8-8.5$, the proportion, \%, of the double-substituted orthophosphate HPO42- (95.12\%-98.39\%) compared to the single-substituted H2O4- (4.88\%$1.60 \%$ ) is maximum. Thus, in May and September 2018, the phosphates were represented mainly by di-basic orthophosphate. In September 2015, the share of HPO42- was also 
greater than the share of $\mathrm{H} 2 \mathrm{PO} 4-$, since\% $\mathrm{HPO} 42-$ at $\mathrm{pH} 7$ is equal to 66.10 , and\% $\mathrm{H} 2 \mathrm{PO} 4-$ is equal to $33.90 \%$.

At $\mathrm{pH}$ level of 8.2 , only $7 \%$ of ammonia is present in water in the form of free ammonia, and the remaining $93 \%$ is in the form of ammonium; Consequently, during the period of research in the Tsimlyansk reservoir in $\mathbf{2 0 1 5}$ and 2018 ammonia was present in dissolved form, in the form of ammonium ions. As $\mathrm{pH}$ of the water increases, the danger to aquatic organisms increases, since free ammonia is more toxic than ammonium nitrogen.

The number of indicative biological characteristics of eutrophication of water bodies can be attributed to an increase in the content of chlorophyll "a". High concentrations of chlorophyll "a" are, as a rule, a response to an increase in the content of organic nutrients in water, and evidence of a high biomass of algae in the water column. In addition, chlorophyll "a" concentrations are an important indicator of the magnitude of the load of nutrients and potential hypoxia. In order to perform an indirect assessment of the productivity of the Tsimlyansk reservoir waters by the content of chlorophyll "a", in the autumn expedition of 2015 and the spring expedition of 2018, the corresponding definitions of chlorophyll "a" were carried out. In addition, in September 2015, concentrations of gross nitrogen and phosphorus were determined. The content of chlorophyll "a" and the ratio of $\mathbf{N}: \mathbf{P}$ in the waters of the Tsimlyansk reservoir in September 2015 are presented in Figure 3.

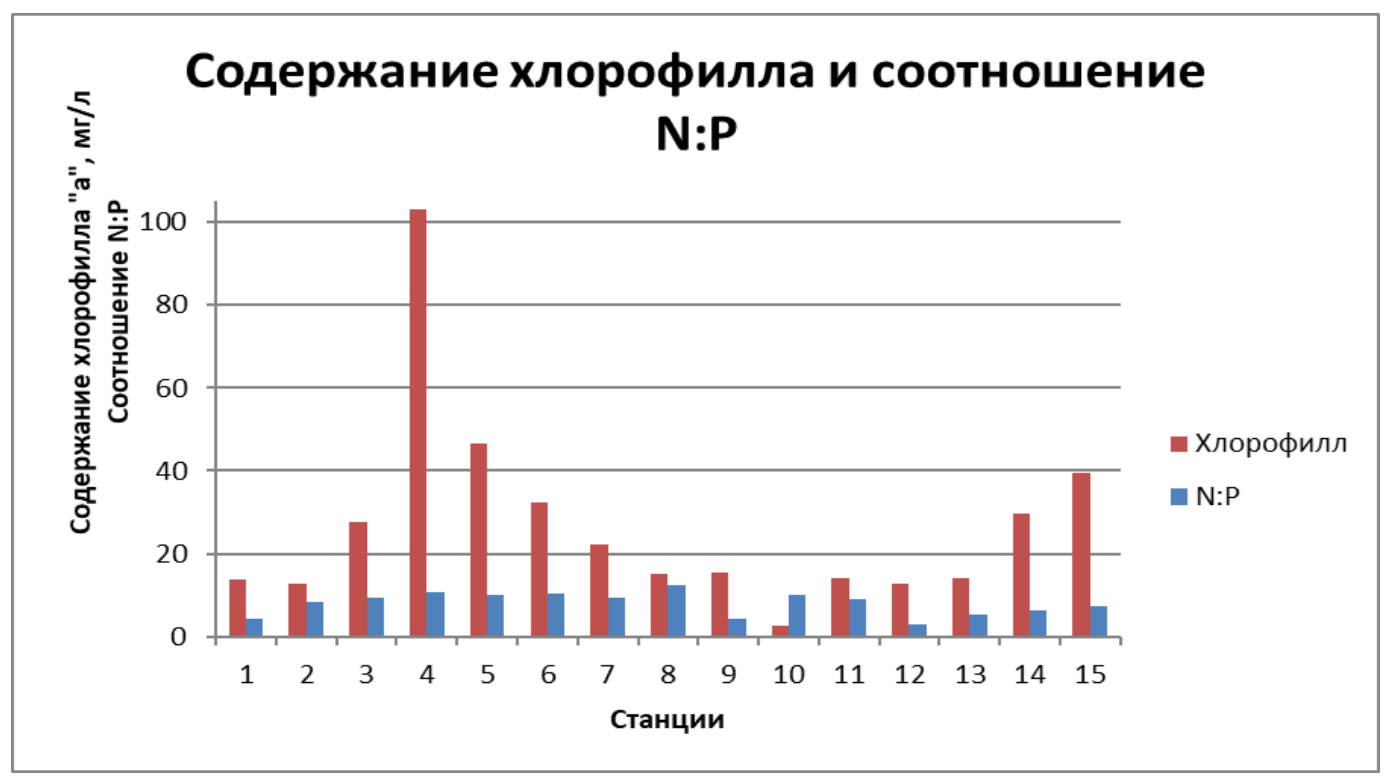

Figure 3. The content of chlorophyll a and the ratio N:P in the waters of the Tsimlyansk reservoir in September 2015

According to the results of the expedition in September 2015, the content of chlorophyll "a" in the surface horizon varied from $2.7 \mathrm{mg} / \mathrm{l}$ to $103.2 \mathrm{mg} / \mathrm{l}$, averaging $25.0 \mathrm{mg} / \mathrm{l}$. The average of total content in $\mathrm{N}$ and $\mathrm{P}$ concentrations were $1.7 \mathrm{mgN} / \mathrm{L}$ and $0.2 \mathrm{mgP} / \mathrm{L}$, respectively, and the $\mathrm{N}: \mathrm{P}$ ratio was on average 8.5. The water column was almost always saturated with oxygen: the DOC changed over the water area from $78 \%$ to $128 \%$. The highest content of chlorophyll "a" (103.2; 46.6; 39.4; 32.5) was observed, respectively, at stations 4; 5; 15; 6 , the smallest one at station 10 . It is noteworthy that the change in the N:P ratio did not always correspond to changes in the content of chlorophyll "a".

In May 2018, the content of chlorophyll "a" in the surface horizon ranged from 4.19 $\mathrm{mg} / \mathrm{l}$ to $20.0 \mathrm{mg} / \mathrm{l}$ and averaged $9.9 \mathrm{mg} / \mathrm{l}$. The temperature of the water was in the range of $15,8{ }^{\circ} \mathrm{C}-22,0^{\circ} \mathrm{C}$, and the average temperature was $19,7^{\circ} \mathrm{C}$. At stations $3 ; 4$ and 5 , the 
content of chlorophyll "a" was maximum for a given period of time $(20.0 ; 19.06 ; 17.93)$, at stations 14 and 9 it was minimum (4.19 and 4.26).

The zones where the weighted average concentration of chlorophyll "a" in the photic layer exceeds 1 ppm during the vegetation period of phytoplankton can be considered highly productive. In accordance with the accepted classification of water trophism according to the content of chlorophyll "a", proposed in [1], and based on the data obtained, the waters of the studied water area of the Tsimlyansk reservoir during the observation period can be characterized as eutrophic, highly productive.

The ratio of the concentration of gross nitrogen to the concentration of gross phosphorus $(\mathrm{N}: \mathrm{P})$, the size of which determines the response of phytoplankton to biogenic elements, is also informative. It is believed that the development of algae is limited by nitrogen at $\mathrm{N}$ : $\mathrm{P}$ $<10$, phosphorus at $\mathrm{N}: \mathrm{P}>15-17$, and in the range $\mathrm{N}: \mathrm{P}=10-15$, close to the ratio of elements in the biological cellular material, the primary production is practically not limited one of the considered elements [10]. Thus, it turns out that in September 2015, in waters of 10 stations, primary production was limited by nitrogen, since the $\mathrm{N}$ : $\mathrm{P}$ ratio was less than 10 . At 5 other stations, primary production was not limited either by nitrogen or phosphorus, because the ratio N:P was in the range of $10-15$. The average value for this observation period was 8.5, which indicates that nitrogen was limited. In September 2018, the average value of the $\mathrm{N}$ : $\mathrm{P}$ ratio was 3.7 , which also indicated that the primary production was limited by nitrogen.

At stations where primary production was not limited by either nitrogen or phosphorus, elevated chlorophyll a concentrations were often, but not always, observed. The concentration of chlorophyll "a" is an indirect indicator of phytoplankton biomass. The trophic level in terms of phytoplankton biomass and chlorophyll concentration "a" may differ slightly. Concentrations of chlorophyll "a" vary widely by season, year, place, since concentrations are determined by pollution, temperature, lighting, seasons, and climatic conditions.

At stations where primary production was not limited by either nitrogen or phosphorus, elevated chlorophyll a concentrations were often, but not always, observed. The concentration of chlorophyll "a" is an indirect indicator of phytoplankton biomass. The trophic level in terms of phytoplankton biomass and chlorophyll concentration "a" may differ slightly. Concentrations of chlorophyll "a" vary widely by season, year, place, since concentrations are determined by pollution, temperature, lighting, seasons, and climatic conditions.

It should be noted that with intensive mixing of water, such as, for example, in coastal waters, the surface concentration of chlorophyll "a" reflects its weighted average content in the layer, in deep-water zones, depending on the season and geographic location, the maximum of chlorophyll "a" on separate horizons from 10-20 m to 50-70 m, in some cases exceeding its quantity at the surface by 8-10 times. Therefore, to characterize the productivity of water, it is necessary to use its weighted average content in the photic layer, or the total [1].

According to the results of the expeditionary work in 2011, 2015 and 2018 the following conclusions can be drawn.

Based on the recorded concentrations of chlorophyll "a", the waters of the studied water area of the Tsimlyansk reservoir can be characterized as highly productive (eutrophic). The steady relationship between the distribution of chlorophyll "a" and the hydrochemical characteristics of the water area confirms its informative capabilities. By virtue of its availability, efficiency, and sufficiently detailed spatial-temporal resolution, satellite information can significantly complement the data obtained by traditional contact methods.

The $\mathrm{N}$ : $\mathrm{P}$ ratios during the observation period indicated that the primary production was limited by nitrogen, but at several stations in September 2015, the primary production was not limited by either nitrogen or phosphorus. 
In our opinion, the presentation of the results of hydrochemical studies in the form of specific concentrations of substances and their relationship to MACs is more interesting and informative than the approach taken to 2002 to assessing the quality of water in water bodies using the specific combinatorial index of water pollution (SCIWP).

The long-term dynamics of the content of the determined parameters under different water conditions did not have pronounced tendencies; in general, the concentrations of nutrients in all field research are comparable, subject to seasonal fluctuations, are in accordance with natural mechanisms and under anthropogenic influence. The content of nutrients in the waters of the Tsimlyansk reservoir in low-flow and high-flow years are expressed by values of the same order. It is possible that the concentrations of biogenic substances in the reservoir do not have a significant relationship with low- flow and high-flow year. To come to a certain conclusion, it is necessary to continue the accumulation of information.

The publication was prepared in the framework of the implementation of the Southern scientific center of Russian Academy of Science, No. of the project AAAA-A18118122790121-5; The work was supported by the Russian Foundation for Basic Research and the Russian Geographical Society in the framework of the research project No.17-0541145 RGS "Study of the transformation of the environment and biota of the Tsimlyansk reservoir and the Lower Don under conditions of climate change."

\section{Лumepamypa}

1. Мордасова Н. В. Косвенная оценка продуктивности вод по содержанию хлорофилла // Научные труды ВНИРО. 2014. Т. 152. С. 41-56.

2. Наставления гидрометеорологическим станциям и постам. Вып. 9. Л.: Гидрометеоиздат, 1968.

3. РД 52.24.381-2006. Массовая концентрация нитритов в водах. Методика выполнения измерений фротометрическим методом с реактивом грисса. Ростов-наДону, 2006.

4. РД 52.24.486-2009. Массовая концентрация аммиака и ионов аммония в водах. Методика выполнения измерений фотометрическим методом с реактивом несслера. Ростов-на-Дону, 2009.

5. РД 52.24.528-2012. Руководящий документ. Массовая концентрация нитратов в водах. Методика измерений фотометрическим методом с сульфаниламидом и $\mathrm{N}$-(1-нафтил)этилендиамина дигидрохлоридом после восстановления сульфатом гидразина. Ростов-на-Дону, 2012.

6. Руководство по химическому анализу морских и пресных вод при экологическом мониторинге рыбохозяйственных водоемов и перспективных для промысла районов Мирового океана. М.: ВНИРО, 2003. 202 с.

7. Сорокина В.В., Бердников С.В. Биогенная нагрузка Дона и Кубани на экосистему Азовского моря. Водные ресурсы, 2018, Т. 45. № 6. С. 670-684.

8. Сидиропуло С.Г. Математическое моделирование переноса загрязнения в Цимлянском водохранилище: Автореф. дис. ...канд. тех. наук. Ростов н/Д, 2007.

9. Усова E.B., Воробьёв E.B. Мониторинг загрязнения реки северский донец нитритами и нитратами // Водные ресурсы России: Современное состояние и управление: Материалы Всероссийск. научно-практ. конференции (г. Сочи, 8-14 октября 2018 г.). Т. І. Новочеркасск: ЛИК, 2018. С. 183-189.

10. Smith V.H. The nitrogen and phosphorus dependence of algal biomass in lakes: an empirical and theoretical analysis // Limnol. Ocearnogr. 1982. Vol. 23. P. 1248-1255. 


\section{References}

1. Mordasova N. V. Kosvennaya otsenka produktivnosti vod po soderzhaniyu khlorofilla. [Indirect Estimation of Water Productivity in Chlorophyll Content]. Scientific works of VNIRO. 2014. V. 152. pp. 41-56 (in Russian).

2. Nastavleniya gidrometeorologicheskim stantsiyam i postam. [Instructions to hydrometeorological stations and posts]. Issue 9. Leningrad: Gidrometeo-publisher, 1968 (in Russian).

3. RD 52.24.381-2006. Massovaya kontsentratsiya nitritov v vodakh. Metodika vypolneniya izmereniy fotometricheskim metodom s reaktivom grissa. [Mass concentration of nitrite in waters. The method of measurement by photometric method with a reagent griss]. Rostov-on-Don, 2006 (in Russian).

4. RD 52.24.486-2009. Massovaya kontsentratsiya ammiaka i ionov ammoniya v vodakh. Metodika vypolneniya izmereniy fotometricheskim metodom s reaktivom nesslera. [Mass concentration of ammonia and ammonium ions in waters. Methods of measuring by photometric method with Nessler's reagent.]. Rostov-on-Don. 2009 (in Russian).

5. RD 52.24.528-2012. Rukovodyashchiy dokument. Massovaya kontsentratsiya nitratov v vo-dakh. Metodika izmereniy fotometricheskim metodom s sul'fanilamidom i N-(1naftil) etilendiamina digidrokhloridom posle vosstanovleniya sul'fatom gidrazina. [Guidance document. Mass concentration of nitrates in water. Photometric measurement method with sulfanilamide and N- (1-naphthyl) ethylenediamine dihydrochloride after reduction with hydrazine sulfate]. Rostov-on-Don. 2012 (in Russian).

6. Rukovodstvo po khimicheskomu analizu morskikh i presnykh vod pri ekologicheskom monitoringe rybokhozyaystvennykh vodoyemov i perspektivnykh dlya promysla rayonov Mirovogo okeana. [Manual on the chemical analysis of marine and fresh water in the environmental monitoring of fishing reservoirs and promising areas for fishing of the oceans]. Moscow: VNIRO, 2003. 202 p. (in Russian).

7. Sorokina V.V., Berdnikov S.V. Biogennaya nagruzka Dona i Kubani na ekosistemu Azovskogo morya. Vodnyye resursy. [The nutrient load of the Don and Kuban on the ecosystem of the Azov Sea. Water resources]. 2018. V. 45. No. 6. pp. 670-684 (in Russian).

8. Sidiropulo S.G. Matematicheskoye modelirovaniye perenosa zagryazneniya v Tsimlyan-skom vodokhranilishche. [Mathematical modeling of pollution transfer in the Tsimlyan reservoir]. Abstract of thesis ... PhD in Technical Sciences. Rostov-on-Don, 2007 (in Russian).

9. Usova Ye.V., Vorob'yov Ye.V. Monitoring zagryazneniya reki severskiy donets nitritami i nitratami. Vodnyye resursy Rossii: Sovremennoye sostoyaniye i upravleniye. [Monitoring of river pollution Seversky Donets nitrites and nitrates. Water Resources of Russia: Current State and Managemen]. The proceedings of All-Russian scientific-practical conference (c. Sochi, 8-14 October 2018). V.I. Novocherkassk: LIK, 2018. pp. 183189 (in Russian).

10. Smith V.H. The nitrogen and phosphorus dependence of algal biomass in lakes: an empirical and theoretical analysis. Limnol. Ocearnogr. 1982. V. 23. pp. 1248-1255. 